\title{
ANALYSIS OF ORGANIZATIONAL JUSTICE: A CROSS SECTIONAL STUDY OF UNIVERSITY TEACHERS
}

\author{
Nazir Haider Shah \\ Assistant Professor, \\ University of Kotli, \\ AJ\&K, Pakistan \\ Email: nazirshah786@gmail.com

\section{Nadia Nazir} \\ Lecturer, \\ Mohi-ud-Din Islamic University, Nerian Sharif, \\ AJ\&K, Pakistan \\ Email: nadianazir481@yahoo.com

\section{Mahek Arshad} \\ Controller of Examination, \\ Bilquis Postgraduate College for Women, PAF, Rawalpindi, \\ Punjab, Pakistan \\ Email: mehakrshd@gmail.com
}

\begin{abstract}
The present research was conducted with the purpose to investigate the role of organizational justice on the lives of university teachers and to investigate the relationship between dimensions of organizational justice among university teachers. The study was descriptive in nature and survey method applied for the collection of data. All the university teachers working in universities of Islamabad were taken as a population of the study. 200 university teachers were taken as a sample of the study through a simple random sample technique. Organizational Justice Measurement Instrument (OJMI) developed by Ledimo (2015) was used in this research as a research instrument. The instrument comprised of 39 items. Data were collected through personal visits of the sampled universities. The data were collected through mean, standard deviation and correlation. The finding of the study revealed that there was a significant relationship found between the dimensions of organizational justice among university teachers. According to the findings of the study, it is recommended that supervisors as well as higher authorities in organizations may focus on all the dimensions of organizational justice equally.
\end{abstract}




\section{KEYWORDS}

Organization, Justice, University Teachers

\section{INTRODUCTION}

Justice is the mainly vital principle in a person's social as well as organizational life. Codes of justice prevailing in society facilitate community to determine their collective as well as individual mutual responsibilities, social accountabilities and civil rights, and describe the reasons and acts on which society will reward them. Justice is a moral and legal principle. The word organizational justice refers to how employees perceive managers' decisions and practices and their perceptions of organizational justice or work-related attitudes and behaviors. Establishing justice is considered to be in the best interest of humanity on earth. It has been the subject of philosophical research since ancient times. Without this structure, any social organization regarded as a symbol of civilization will cease to exist. This is one of the basic principles of any social association. Obviously, in today's era where the level of awareness has reached a new level, people attach great importance to the sense of justice of employees in the workplace (Lambert, 2003).

The organization is a social system of human assets. Organizations require efficient employees to achieve their aims and goals, because without including their tireless efforts and commitment, organizations cannot succeed. Moral and employee satisfaction are the two most reflective variables that affect organizational performance. Job satisfaction is directly related to the behavior of an individual in the workplace. It is a collection of employees' feelings and beliefs about their current job (Aziri, 2011). A special factor that affects employee job satisfaction is called organizational justice. This refers to the fair treatment of employees. It refers to employees who are fair to results, procedures and interactions, which make them feel that they are equally treated and fairly rewarded for their true contribution towards the organization. Rewards not only includes financial benefits but can be other benefits like free trips, letter of appreciation etc. Employees having great level of job satisfaction are surely to reach higher levels of quality performance, high productivity and sense of commitment (Al-Zu'bi, 2010).

Organizational justice can be simply understood as an overall fair understanding of compensation, promotion opportunities, responsibilities, methods and interpersonal relationships. These perceptions are considered important prerequisites for several work attitudes and results, such as satisfaction, trust, commitment, motivation, sabotage, intention to leave, absenteeism, and organizational citizenship. This, in turn, is related to the efficiency and effectiveness of the organization, which affects its longterm success. As a result, it becomes even more necessary for organizations to pay enough attention to this concept of justice. In order for employees to be satisfied, 
organizations must be fair in distribution, procedures, and interactive justice systems. This is especially important for educational institutions, where dedicated teachers are essential to achieving the basic goals of their survival. These institutions are designed to inspire society by educating young people as best they can. Only through the efforts of dedicated teachers these organizations can make a real impact on the world. Therefore, it is necessary to provide teachers with such an environment so that they can feel fair in all aspects of their work (Lambert, Hogan \& Griffin, 2007).

\section{LITERATURE REVIEW}

Justice is the most important of among other principles in organizational and social life. Organizational justice is related to fairly treatment of all employees (Randeree, 2008). Historically, Homans (1961) first proposed the concept of justice in organizations in the form of distributive justice. However, it is Adams' equity theory that promotes this form of justice in organizations. Fairness theory states that one employee compares its input-output ratio to the ratio of other employees. When these proportions are disproportionate, he considers the situation unfair. Greenberg (1990) coined the term organizational justice and defined it as an employee's sense of fairness in the workplace. In addition, these perspectives are critical to personal satisfaction and better organizational performance. Therefore, the focus should be on putting more effort into achieving that goal.

Taşdan (2008) suggested in his research that the most vital values in the life of educational organizations is justice. According to Seligman (2011), subjective wellbeing is a multidimensional structure composed of positive emotions, participation, positive interpersonal relationships, meaning, and achievement or accomplishment. From elementary school teachers to university professors, teachers have the highest job-related stress index (Andrade \& Cardoso, 2012). Therefore, it was studied that the working conditions and subjective well-being categories of the professional were relevant. Research on job needs and teacher satisfaction of university teachers is particularly important (Medeiros, 2011). Existing literature has extensively identified dimensions of organizational justice, namely, distribution, procedural, interactive, temporal, spatial, strategic direction and informational justice.

\section{Distribution justice}

Fairness felt in allocating resources in an organization is called distribution justice. People in the organization are sensitive to knowing whether the allocation of resources meets the proper norms. If the allocation of resources is rewards, responsibilities and other outcomes are within specification, distribution justice is said to have occurred. Moreman (1991) simply defines it as the fairness of the results employees get from the organization, such as compensation, promotion, etc. 


\section{Procedural justice}

After a decade of research by Adams (1965), Thibaut and Walker (1975) newfangled area of organizational justice, known as procedural justice was emerged. Procedural justice emphases on the process used to define the results. Procedural justice is the fairness of the processes used in making decisions related to the allocation of organizational resources. Employee perception process becomes fair when they encourage fair rewards and other outcomes. When an employee receives results that are inconsistent with his wishes, the procedure used to determine such results seems fair, which will reduce his dissatisfaction. Folger and Konovsky (1989) pointed out the main difference between distribution and procedural justice in the work organization. He pointed out that distributional justice means the fairness of the compensation received by employees; while procedural justice means fairness of the method for determining these amounts. A study conducted by Taylor (2003) showed the use of procedural justice in law and order management institutions and its impact on public trust and confidence. Taylor (2003) research suggests that procedural justice is a response to the public's concern for fairness in exercising legal authority.

\section{Interactive justice}

Bies and Moag (1986) introduces a new dimension to the construction of organizational justice and calls it "interaction justice." Mikula, Petrik, and Tanzer (1990) report that a significant amount of injustice is related to the concept of interactive justice, not to distribution or procedural issues. Employees value the way they treat their supervisors when they interact with them. Interactive justice is further subdivided into two components: interpersonal justice and information justice. Interpersonal justice is the respect, politeness, and dignity of people, or the understanding when making decisions, and a full explanation of the fairness, timeliness, and authenticity of information is information justice (Colquitt, 2001). According to Pilvinyte (2013), the fairness of interaction is characterized by the sympathy, respect and courtesy which employees obtain from their supervisors in the induction process. It is predominantly to change the response to results, as compassion can make employees feel better even when the results are not ideal. This may be a relationship between employees and their colleagues or managers. In the context of this study, fairness of interaction means a fair perception of interpersonal relationships among all organizational members with emphasis on interdepartmental relationships.

\section{Temporal justice}

In social justice, Goodin (2010) introduced the concept of justice in the distribution of 
time, especially the discretion of time. Temporal autonomy is the freedom to control time. Each person in this world only has 24 hours per day. Some people utilize their time better than others to obtain greater satisfaction and achievement, but the way one effectively uses their time has nothing to do with their own time rights. When we say that someone has more time than others, it means that they are less restricted and have more time to choose between hobbies. Temporal justice in an organization is related to "fair distribution of time". How an employee perceives the time they should be given to complete the task each day. Time is a resource and may be mistaken for it to be part or extension of distributive justice, but it must be distinguished from the fact that it is not the result, nor the ratio of input to result in fairness theory, and is replaced by the fairness of the right to time for employees. Organizations must divide working time equally among employees, regardless of whether they are single or married, part-time students or full-time workers, and whether there are dependent family members, as everyone has the right to use their discretionary time so that they can reduce stress and becomes satisfied with their work and increases productivity.

According to Gooden (2010), from a fairness of time perspective, what is most worrisome is how a set of policies and practices will affect the independence of different people's time differently. If the employee is forced to work late, this will reduce his / her personal time, his time with family, study time, etc. In turn, this will increase tension and reduce productivity. Time justice is a different concept from work-to-life balance. The work-life balance is a result of employees being conducted only according to the time set by their organization. This understanding of justice requires the concept of using time during business hours. It is impossible to strike a balance between work and life if the manager does not give equality to employees throughout working hours. It is similar to the concept of "hidden justice" that organizational employees search for in a timely manner. Positive perception of time is a psychological need that can improve employee productivity. Therefore, time justice can be used as a new dimension of organizational justice in the regulatory environment. Time independence is very unequal, so institutions must intervene and design policies to distribute time evenly among employees regardless of their status, such as part-time students, single mothers, or employees with dependent family members.

\section{Spatial justice}

It refers to perceptions of the geographical distance of resources, asymmetric development comparisons or backwardness in these resources between diverse subdivisions of the organization based on geographical distance. Spatial word refers to area, location, or location (Glick, Hyde \& Sheikh, 2012) or related to space (Hawker, 2006). In a broad sense, spatial justice refers to the spatial or geographical aspect of justice. It involves the equitable distribution of resources of social value in space and the opportunity to use these resources. Geographical asymmetry or underdevelopment 
also provides a framework for empathetic the processes that create injustice. Due to geographic location, the organization imposed location discrimination. An understanding and analysis of the creation of an organization's improper geography and spatial structure can help explain the organization's spatial injustices and thus develop territorial policies aimed at addressing these issues. Spatial justice affects resource allocation and decision-making processes throughout the region (Soja, 2008). Therefore, it is important to establish a fair space policy to ensure the satisfaction and commitment of employees in the organization. For example, there are not enough facilities or services required for the health and well-being of members of an organization in one location compared to the organization or health available in other locations or branches / departments. We can give another example like the allocation of resources, such as budget (for ATMs, printers, office furniture, etc.) is unfairly allocated, so some remote areas are at a disadvantage than others. Bank branches located in developed areas within villages or cities (Glick, Hyde \& Sheikh, 2012).

\section{Strategic direction justice}

Depends on formulating, communicating and implementing the organization's vision and mission statement to express a fair view. Describe strategic direction as the organization's primary goals founded on its vision, mission, goals, operating plans, and organizational value (McShane \& Von Glinow, 2005; Mullins \& Christy, 2010). The strategy mentions to procedures and methods that management designed to achieve successful organizational performance. One of the ways in which an interest can be expressed in equitable development and in the ethical implementation of its goals is to develop a strategic, justice-oriented direction. The focus in a fair strategic direction is to consult with related stakeholders in the decision-making procedure. The purpose of the negotiation method is to set a clear and attainable common organizational goal (Tonder, 2004). Mullins and Kristi (2010) believes that a well-documented good goal provides a unified direction and helps provide direction to the process and handling of the organization. A moral implementation of strategic direction is included in the current value and resource allocation within the organization to achieve specified goals (Brown, 2006; Werner, 2007). The deficiency of appropriate assets creates the strategic direction unreasonable as the members' efforts to achieve this goal are challenging and unfair.

\section{Informational Justice}

It states towards the description, justification and material given by the decision maker about why the results were distributed in a particular way (Pilvinyte, 2013). For this kind of justice, the information communicated within the organization must be complete, realistic, truthful, well-timed and honest. Therefore, information justice refers to whether you are true and provide satisfactory justification for all beneficiaries of the info (Cropanzano et al., 2007). Colquitt (2001) argued that information justice 
helps employees assess the structural aspects of an organization's processes. For this research, information justice mentions to dissemination and equality in information organization with special allusion to inner and exterior communications or knowledge management systems.

Based on literature review following conceptual framework has been developed which highlights indictors of organizational justice:

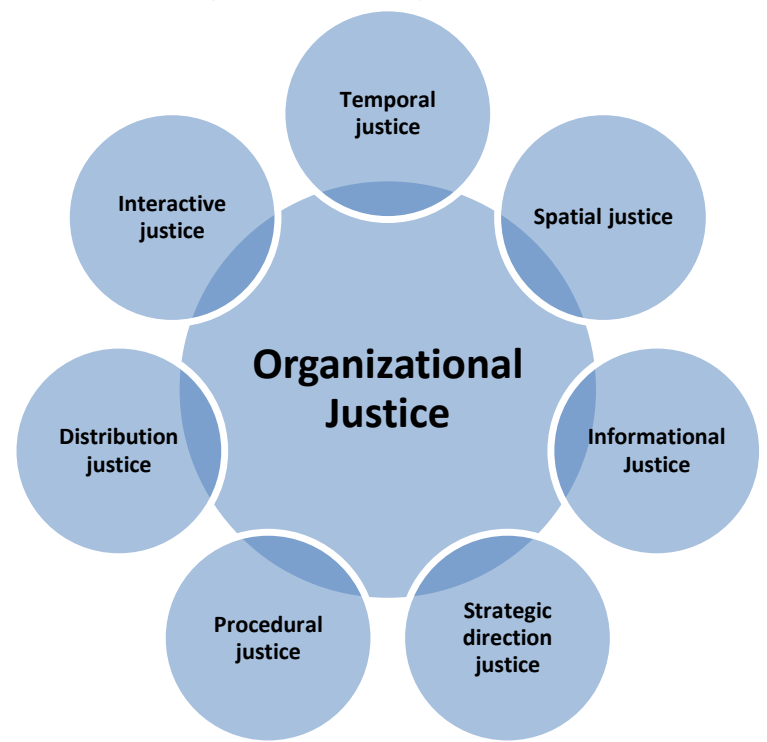

Figure 1. Conceptual Model of Organizational Justice

Researchers acknowledge that, in addition to assessment results and procedures, employees have observed fairness in interpersonal treatment in the workplace. Organizational justice is considered as a basic necessary condition for the effective operation of an organization. These perspectives are related to many of the organization's key results. In their meta-analysis study, Cohen-Charash and Spector (2001) found that procedural justice and distributive justice are important determinants of departure intentions, while interactive justice is relatively weak. The study further revealed that distribution and procedural justice are important predictors. Colkitt (2001) also found that workplace justice is an important factor in determining job performance. It has also been found that procedural justice and distributional justice affect employee commitment levels. Therefore, it can be said that justice is the key determinant of the survival and growth of any organization.

Yilmaz (2010) determines the perceptions of organizational justice among teachers in public schools high schools and whether these perceptions differ between gender, age, 
seniority, branches, educational background, number of students and number of teachers. Participants in the study included 222 public middle school teachers. The study found that participants had a positive view of organizational justice, and their views differed based on age, seniority, and number of students, while their gender, branch, educational background, and number of teachers did not differ. A study surveyed teachers of University of Kashmir regarding their perspective on organizational justice with a focus on distribution justice, procedural justice, and interactive justice. Data was collected with the help of questionnaires by Niehoff and Moorman (1993). The survey results show that there is a moderate degree of organizational justice in universities, and there is a significant positive correlation between these three aspects (Majeed, Peerzadah, Mufti \& Noor, 2018).

Khalil and Sharaf (2014) examined the impact of organizational justice on the outcomes of teacher work in Egypt. A survey of 308 teachers from 31 schools was conducted and statistical analysis was performed using Amos 18 and SPSS 20. The results show that, compared with teachers 'job satisfaction, distribution justice has a greater relationship with procedural justice, and interactive justice has a greater relationship with procedural justice than teachers' organizational commitment. It was found that organizational justice has an indirect effect on turnover intentions through organizational commitment. The results show that teachers' understanding of organizational justice and organizational commitment in public schools differs significantly from that of private schools. On the other hand, there is no significant difference between their job satisfaction and turnover intention. Study empirically demonstrates the importance of organizational justice in developing outcomes related to active work in developing countries. It enables school administrators to develop appropriate strategies and policies to achieve better results, especially under difficult working conditions.

Al-Zubi (2010) studies the relationship between organizational justice and job satisfaction, and employees' perceptions of workplace justice. Further investigated the relationship between these judicial procedures in the Jordanian environment. Collecting data by distributing questionnaires among 229 employees of Electric Industries. The research results show that there is only one important relationship between respondents' age and their views on organizational justice, and there is a positive correlation between organizational justice and job satisfaction. The job satisfaction of employees depends on the organizational impartiality of the manager.

\section{RESEARCH OBJECTIVES}

1. To find out the role of organizational justice on the lives of university teachers.

2. To explore the relationship between dimensions of organizational justice 
among university teachers.

\section{RESEARCH HYPOTHESES}

1. There is no role of organizational justice on the lives of university teachers. 2. There is no significant relationship between dimensions of organizational justice among university teachers

\section{RESEARCH METHODOLOGY}

In order to achieve the objective of the research, a quantitative research design was used. The population of the study was all the university teachers working in the universities of Islamabad. A simple random sample approach was used to choose the sample. The sample comprised of 200 university teachers. Organizational justice was measured by using Organizational Justice Measurement Instrument (OJMI) developed by Ledimo (2015) that contains nine dimensions namely distributive, ethical leadership and management, service delivery innovation, strategic direction justice, interactional justice, informational justice, procedural justice, diversity management justice and student relations justice. The questionnaire was consisted of 59 items but it was delimited to 34 items for this research study. The data were analyzed by using mean, standard deviation and correlation.

\section{RESEARCH FINDINGS}

Table 1

Cronbach's Alpha

\begin{tabular}{lcc}
\hline Dimensions & No. of Items & Cronbach's Alpha \\
\hline Distributive Justice & 05 & .873 \\
Ethical Leadership and Management & 05 & .865 \\
Service Delivery Innovation & 04 & .840 \\
Strategic Direction Justice & 04 & .832 \\
Interactional Justice & 04 & .837 \\
Informational Justice & 04 & .841 \\
Procedural Justice & 03 & .836 \\
Diversity Management Justice & 03 & .886 \\
Student relations Justice & 02 & .870 \\
\hline
\end{tabular}

Table 1 shows the reliability of dimensions of organizational justice. Regarding this tables all the value of cronbach's alpha were reliable.

Table 2

Mean and Standard Deviation of Organizational Justice

\begin{tabular}{lcc}
\hline Dimensions & Mean & Standard Deviation \\
\hline Distributive Justice & 18.7003 & 2.78082 \\
\hline
\end{tabular}




\begin{tabular}{lcc}
\hline Ethical Leadership and Management & 14.7227 & 2.66561 \\
Service Delivery Innovation & 15.6695 & 2.69675 \\
Strategic Direction Justice & 15.5154 & 2.54353 \\
Interactional Justice & 16.4678 & 2.26904 \\
Informational Justice & 11.4006 & 2.31126 \\
Procedural Justice & 10.7171 & 2.43363 \\
Diversity Management Justice & 7.9832 & 1.31104 \\
Student relations Justice & 18.6359 & 3.30077 \\
\hline
\end{tabular}

Table 2 shows the mean and standard deviation of dimensions of organizational justice. According to this table distributive justice $(\mathrm{M}=18.7003, \mathrm{SD}=2.7808)$ and student relations justice $(\mathrm{M}=18.6359, \mathrm{SD}=3.3007)$ have high mean score as compared to all other dimensions. Moreover, mostly university teacher are satisfied with distributive justice and student relations justice in their institutions.

Table 3

Inter-correlation between dimensions of Organizational Justice

\begin{tabular}{|c|c|c|c|c|c|c|c|c|c|}
\hline \multirow{2}{*}{\multicolumn{10}{|c|}{$\begin{array}{l}\text { Variables } \\
\text { Distributive }\end{array}$}} \\
\hline & & & & & & & & & \\
\hline Justice & & & & & & & & & \\
\hline Ethical & .127 & & & & & & & & \\
\hline $\begin{array}{l}\text { Leadership } \\
\text { and }\end{array}$ & & & & & & & & & \\
\hline Management & & & & & & & & & \\
\hline Service & .273 & .540 & & & & & & & \\
\hline Delivery & & & & & & & & & \\
\hline Innovation & & & & & & & & & \\
\hline Strategic & .204 & .594 & .750 & & & & & & \\
\hline Direction & & & & & & & & & \\
\hline Justice & & & & & & & & & \\
\hline $\begin{array}{l}\text { Interactional } \\
\text { Justice }\end{array}$ & .297 & .433 & .712 & .835 & & & & & \\
\hline $\begin{array}{l}\text { Informational } \\
\text { Justice }\end{array}$ & .219 & .527 & .692 & .799 & .758 & & & & \\
\hline $\begin{array}{l}\text { Procedural } \\
\text { Justice }\end{array}$ & .172 & .637 & .712 & .956 & .808 & .817 & & & \\
\hline $\begin{array}{l}\text { Diversity } \\
\text { Management } \\
\text { Justice }\end{array}$ & .882 & .079 & .106 & .063 & .191 & .105 & .045 & & \\
\hline
\end{tabular}


PJER, Vol 3, Issue 2 (2020)

Analysis of organizational...

\begin{tabular}{lllllllll}
\hline $\begin{array}{l}\text { Student } \\
\text { relations }\end{array}$ & .484 & .415 & .382 & .315 & .276 & .269 & .281 & .014 \\
Justice & & & & & & & & \\
\hline
\end{tabular}

To examine the relationships among various dimensions of Organizational justice, Pearson's correlation coefficient test was applied. This indicates that an increase in the perception of one dimension of justice will lead to an increase in other dimensions and vice versa. Table 3 also indicates that amongst these dimensions, there exists strong positive correlation between interactional justice and strategic direction justice $(r=$ $0.835, \mathrm{p}<0.01)$. In addition, there was found no correlation between the dimensions of student relations justice and diversity management justice $(r=0.014, p>0.05)$ among the sample respondents.

\section{CONCLUSION AND DISCUSSIONS}

The main objective of the present study was to explore the perception of organizational justice among teaching faculty in the Universities of Islamabad. An in-depth analysis of the data collected revealed that the sample respondents perceive very high level of distributive justice and student relations in the Universities of Islamabad. This indicates that the faculty is more confident about fairness with regard to the distribution of rewards like salary and perks, responsibilities and workload. The study also found moderate level of Diversity Management Justice perceived by the sample respondents, indicating that the faculty feels moderate level of fairness with regard to the treatment from higher authorities and explanations provided for making decisions regarded to their job. Kalay (2016) also found same results in his research.

The present study also found strong positive correlations among the dimensions of organizational justice among the sample respondents. This implies any increase in fairness perception of Faculty on any of these dimensions is likely to increase their perception of fairness on other dimensions as well. This goes in line with previous researchers' studies who have stated that these three dimensions are interrelated but distinct (Yadav \& Yadav, 2016; Greenberg, 2005). Apparently the correlation between interactional justice and strategic direction justice is the strongest one. This delineates that when the Faculty is treated fairly by the higher authorities and are provided adequate explanations for taking certain decisions regarding their jobs, they tend to perceive the procedures adopted for such decisions to be fair and vice versa. Choudhary, Deswal \& Philip (2013) also revealed the same results.

It was concluded that university teachers are satisfied with distributive justice and students' relation justice in their organization. 


\section{RECOMMENDATIONS}

There is a positive and significant relationship between all the dimensions of organizational justice, so:

1. The result shows that there is a high level perception found in distributive justice and student relations so, the university may be fair in its own place, but it is the perception of its teaching faculty that matters. So the university administration should try to provide such work environment wherein teachers feel more fairness with regard to the procedures used to determine the outcomes. There should be more consistency with regard to the processes and methods employed in determining the outcomes.

2. As indicated by results that interactional justice and strategic direction justice are strongly correlated with overall justice perceptions, it is therefore suggested to enhance and maintain good interpersonal relationships at the university. The teachers should perceive fair treatment in every aspect of work, which in turn will lead to positive work outcomes like commitment, job satisfaction, trust, organizational citizenship behaviour and the like. This will eventually lead to the betterment of the institution in general and add to its effectiveness and overall efficiency.

\section{REFERENCES}

Adams, J.S. (1965). Inequity in social exchange. In L. Berkowitz, Advances in experimental social psychology,2, 267-299.New York: Academic Press.

Al-Zu'bi, H. A. (2010). A study of relationship between organizational justice and jobsatisfaction. International Journal of Business and Management, 5(12), 102-109.

Al-Zubi, H. A. (2010). A Study of Relationship between Organizational Justice and Job Satisfaction. International Journal of Business and Management, 5(12), 102-109.

Andrade, P. S., \& Cardoso, T. A. O. (2012). Prazer e dor na docência: Revisão bibliográficasobre a sindrome de Burnout. Saúde e Sociedade, 21(1), 129-140. doi:10.1590/S010412902012000100013.

Aziri. B. (2011). Job Satisfaction: A literature Review. Management Research And Practice, 3(4), 77-86.

Bies, R. J. \& Moag, J. S. (1986). Interactional justice: Communication criteria of fairness. RoyLewicki (Ed.), Research on negotiation in organizations, Greenwich, CT: JAI Press.

Brown, T. A. (2006). Confirmatory factor analysis for applied research. New York: Guilford Press.

Choudhary. N \& Deswal. R. K \& Philip, P. (2013). Impact of Organizational Justice on Employees'

Cohen-Charash, Y. \& Spector, P. (2001). The role of justice in organizations: Behavior and Human Decision Processes, 86(2), 278-321.

Colquitt, J. A. (2001). On the dimensionality of organizational justice: A construct validation of a measure. Journal of Applied Psychology, 86, 386-400. 
Colquitt, J.A., Conlon, D. E., Wesson, M.J., Porter C.O.L.H. \& Ng, K. Y. (2001). Justice at the millennium: A meta-analytic review of 25 years of organizational justice research, Journal of Applied Psychology, 86, 425-445.

Cropanzano, R., Bowen, D. E., \& Gilliland, W. (2007). The management of organizational justice. Academy of Management Perspectives, 34-47.

Estudo de caso numa universidade pública (Unpublished master's thesis). Universidade Potiguar, Natal, Rio Grande do Norte.

Folger, R., \& Konovsky, M. A. (1989). Effects of procedural and distributive justice on reactions to pay raise decisions. Academy of Management Journal, 32,115-130.

Glick. J, Hyde. S, Sheikh. A. (2012). Unpublished Raw Data.

Goodin, E. R. (2010). Temporal Justice. Journal of Social Policy. 39(1), 1-16.

Greenberg, J. (1990). Organizational justice: Yesterday, today, and tomorrow. Journal of Management, 16, 399-432.

Greenberg, J. (2005). (Eds.), Handbook of organizational justice, 85-112. (Mahwah, NJ: Lawrence Erlbaum Associates,).

Hawker, S. (9th Ed.) (2006). Little Oxford English Dictionary. New York: Oxford Universit Press.

Homans, G.C. (1961). Social Behavior: Its Elementary Process. New York: Harcourt, Brace \& Wood.

Instrument for a South African Context. Risk governance \& control: financial markets \& institutions. Vol 5, Issue 1, 27-38.

Kalay.F (2016). The Impact of Organizational Justice on Employee Performance: A Survey in

Khalil, H. A. E. \& Sharaf, I. M. (2014). The Impact of Organizational Justice on Teachers' Work Related Outcomes in Egypt with an Integer Programming Model. American Journal of Economics and Business Administration, 6(4), 148-158.

Lambert, E. (2003). Justice in corrections: An exploratory study of the impact of organizational justice on correctional staff. Journal of Criminal Justice, 31, 155-168.

Lambert, E., Hogan, N. \& Griffin, M. (2007). The impact of distributive and procedural justice on correctional staff job stress, job satisfaction, and organizational commitment. Journal of Criminal Justice, 35, 644-656.

Ledimo. O (2016). Development and Validation of an Organisational Justice Measurement

Majeed, S., Peerzadah, S. A., Mufti, S. \& Noor, L. (2018). Perception of Organizational Justice among University Teachers: An Empirical Study. International Journal of Management, Technology and Engineering, 8(XII), 736-743.

McShane, L. S. \& Von Glinow, A. M. (2005). Organizational behavior. (3rd ed.). Boston: McGraw-Hill Irwin.

Medeiros, B. V. (2011). Síndrome de Burnout e a centralidade do trabalho na docência:

Mikula, G., Petrik, B., \& Tanzer, N. 1990. What people regard as unjust: Types and structures of everyday experiences of injustice. European Journal of Social Psychology, 20, $133-149$.

Moorman, R. H. (1991). Relationship between organizational justice and organizational citizenship behaviors: Do fairness perceptions influence employee citizenship? Journal of Applied Psychology,76, 845-855.

Mullins, J. L. \& Christy, G. (2010). Management and Organizational Behaviour. Harlow: Pearson Education Limited. 
Niehoff, B. P. \& Moorman, R. H. (1993). Justice as a mediator of the relationship between methods of monitoring and organizational citizenship behavior. Academy of Management Journal, 36, 527-556.

Pilvinyte, M. (2013). Perceptions of organisational justice, restorative organisational justice, and their relatedness to perceptions of organisational attractiveness. Unpublished master's dissertation. Johannesburg: University of Witwatersrand.

Randeree. K. (2008). Organizational justice: migrant worker perceptions in organizations in the United Arab Emirates. Journal of Business Systems, Governance and Ethics 3(4), 57.

Seligman, M. E. P. (2011). Flourish: A Visionary New Understanding of Happiness and Well Being. New York, NY: Free Press.

Soja, W. E., (2008). The city and spatial Justice. In Spatial Justice, Nanterre, Paris. Available at: http://www.jssj.org/archives/01/05.php\#b. Retrieved on 09-12-2019.

Taşdan, M., \& Yılmaz, K. (2008). Organizational citizenship and organizational justice scales' adaptation to Turkish. TED Ë̆itim ve Bilim Dergisi, 33(150), 87-96.

Thibaut, J., \& Walker, L. (1975). Procedural justice: A psychological analysis. Hillsdale, NJ: Lawrence Erlbaum.

Turkey and Turkish Context. International Journal of Human Resource Studies. Vol.6 (1). 120.

Tyler, R., T., (2003) Procedural Justice, Legitimacy, and the Effective Rule of Law, Crime and Justice, 30, 283-357.

Van Tonder, C. L. (2004). Organizational change: Theory and practice. Pretoria: Van Schaik Publishers.

Werner, A. (2007). Organizational behaviour: A contemporary South African perspective. $\left(2^{\text {nd }}\right.$ ed). Pretoria: Van Schaik Publishers.

Workplace and Personal Outcomes: A Study of Indian Insurance Sector Impact of Organizational Justice on Employees' Workplace and Personal Outcomes: A Study of Indian Insurance Sector. The IUP Journal of Organizational Behavior, Vol. 12(4), 114

Yadav, L. K. \& Yadav, N. (2016). Organizational Justice: An analysis of Approaches, Dimensions and Outcomes. NMIMS Management Review, vol. XXXI,

Yilmaz, K. (2010). Secondary Public School Teachers' Perceptions about Organizational Justice. Educational Sciences: Theory \& Practice, 10 (1), 603-616. 